\title{
The Chiastic Structure of Psalm 106
}

\section{LEE Roy MARTIN ${ }^{1}$ (UNIVERSITY OF SOUTH AFrICA)}

\begin{abstract}
This study describes the chiasm that is embedded within the narrative structure of Psalm 106. The author classifies the psalm as a historical recital of Israel's story, but within the psalm's narrative structure there is a chiasm that emphasizes key parallel elements. These elements draw the reader's attention to the themes of praise, prayer, salvation, rebellion and Moses, to name a few. Psalm 106 focuses on Israel's past failures and Yahweh's generous grace, motifs that highlight the need for repentance and forgiveness in any historical context, but especially in the exilic and postexilic periods.
\end{abstract}

KEYWORDS: chiasm, historical psalms, repentance, prayer, Moses

\section{A INTRODUCTION}

Like Psalms 78, 105, 135, and 136, Psalm 106 can be classified as a psalm of historical recital. ${ }^{2}$ Observing that Psalms 105 and 106 stand side by side, Charles Briggs argued that they were originally one psalm, and Walther Zimmerli called them "twin psalms." 'B Both Psalms 105 and 106 tell the familiar story of Israel, emphasizing the exodus narrative and the ensuing covenant with Yahweh. The two narratives, however, present contrasting versions of Israel's relationship to Yahweh. In Psalm 105, the history Israel is made up of a series of continual victories; but in Psalm 106, the same history consists of repeated episodes of Israel's disobedience. Because of their differing perspectives on Israel's history, it seems reasonable to assume that the two psalms address two different contexts. Psalm 105 calls for celebration, but Psalm 106 demands confession and repentance.

* Submitted: 14/08/2018; peer-reviewed: 11/10/2018; accepted: 14/12/2018. Lee Roy Martin, "The Chiastic Structure of Psalm 106," Old Testament Essays 31 no. 3 (2018): 506-521. DOI: https://doi.org/10.17159/2312-3621/2018/v31n3a6.

1 Prof Lee Roy Martin is a former DTh student of Wilhelm Wessels.

2 Cf. Leslie C. Allen, Psalms 101-150, Word Biblical Commentary 21 (rev. ed., Waco, TX: Word Books 2002), 67.

3 Charles Augustus Briggs and Emilie Grace Briggs, A Critical and Exegetical Commentary on the Book of Psalms, International Critical Commentary (2 vols.; Edinburgh: T. \& T. Clark, 1969), II, 342; Walther Zimmerli, 'Zwillingspsalmen', in idem, Studien zur alttestamentlichen Theologie und Prophetie: Gesammelte Aufsätze Band II,Theologische Bücherei, 51 (Munich: Kaiser, 1974), 261-71. 
This article presents a brief study of Psalm 106, points out the chiastic structure that is embedded within the historical narrative, and suggests contexts in which the psalm's plea for forgiveness might be liturgically appropriate.

\section{B PSALM 106}

\section{The Structure and Gattung of Psalm 106}

Although Frank-Lothar Hossfeld proposes only a three-part structure to Psalm 106, consisting of 1-5, 6-46, and 47-48, ${ }^{4}$ I would argue for five distinct sections, with "Praise Yah" being a call to worship that serves as an inclusion to the psalm, as it does in several hymns of descriptive praise (cf. Pss 113, 115, 117, 135, and 146-150. ${ }^{5}$ The major difference in our outlines, however, is the location of vv. 45. Hossfeld places these two verses outside the main narration, but the fact that the prayer for salvation (v. 4) is repeated in v. 47 convinces me that vv. 4-5 belong with the main part of the narrative. I would outline the psalm as follows:

I. Call to worship - "Praise Yah!" (1a)

II. Thanksgiving, and a blessing on the righteous (1b-3)

III. Prayer for salvation based upon Israel's story (4-47)

A. Opening prayer for forgiveness of sin (4-5)

B. Israel's story of sin and forgiveness (6-46)

1. Wonders of Egypt - yet Israel rebelled (7-12)

2. In the wilderness, Israel tempted God (13-15)

3. In the wilderness, Dathan swallowed by the Earth (16-18)

4. The Golden Calf (19-23)

5. Refusal to enter Canaan (24-27) (cf. Numbers 13-14)

6. Sin and plague at Baal-Peor (28-31)

7. Moses' striking of the rock (32-33)

8. Israel's idolatry in Canaan (34-39)

9. The cycle of the judges (40-46)

C. A prayer for salvation from exile (47)

IV. Closing word of praise (48a)

V. Renewed call to worship - "Praise Yah!" $(48 b)^{6}$

$4 \quad$ Frank-Lothar Hossfeld and Erich Zenger, Psalms 3: A Commentary on Psalms 101-150, trans. Linda M. Maloney, Hermeneia (Minneapolis, MN: Fortress Press, 2011), 86-87. Allen, Psalms 101-150, provides an overview of the various proposals regarding structure (68-70). The variations from one commentator to another are quite small.

5 Oddly, Allen P. Ross, A commentary on the Psalms. 3 vols., Kregel Exegetical Library (Grand Rapids, MI: Kregel, 2011), places the first "Hallelujah" inside the body of the poem, but the concluding "Hallelujah" he puts outside the poem as an "Epilogue" (283).

6 It should be pointed out that v. 48 functions as a concluding doxology to Book IV of the Psalter. However, Mowinckel has proposed, based partly on the citation of Ps 
As was mentioned above, the first and last sections form an inclusio consisting only of "Praise Yah," which is the call to worship. The opening, therefore, suggests a hymn of praise, but the core of the psalm is instead a prayer of confession. ${ }^{7}$ Richard J. Clifford classifies Psalm 106 as a lament, ${ }^{8}$ but Erhard S. Gerstenberger views it as a combination of "Communal Confession" and "Hymnic Instruction." Leslie Allen argues that the combination of hymn and lament in Psalm 106 illustrates the "limitations of the form-critical method,"10 but Walter Beyerlin insists that this new form makes sense in light of religious tensions that were present after 587 BCE, when the praise of God was difficult and needed to be renewed through the use of confession and historical recital. ${ }^{11}$ The second section continues the call to worship and expands upon it by affirming Yahweh's covenant commitment (זס, v. 1b) and mighty works (v. 2). Verse 3 pronounces a blessing upon those who "guard justice and perform righteousness at all times," a pronouncement that later becomes prominent by virtue of the "righteousness" of Phinehas (v. 31).

The third and central section both begins and ends with a prayer for forgiveness and salvation (vv. 4-5 and 47). The psalmist moves from "me" (vv. 4-5) to "we" (v. 6), "a remarkable testimony of solidarity between the individual and nation," 12 indicating the importance of confession not only for the individual

106:48 in 1 Chron 16:36, that v. 48 was not added to the Psalm as a final doxology for Book IV; rather its presence was one of the "causes" of the division of the Psalter into 5 parts. See Sigmund Mowinckel, The Psalms in Israel's worship. 2 Vols in 1 (New York: Abingdon Press, 1967), II, 199. Cf. David Emanuel, From Bards to Biblical Exegesis: A Close Reading and Intertextual Analysis of Selected Exodus Psalms (Eugene, OR: Pickwick, 2012), 87-88, who argues for the following divisions: 1-5, 646,47 , and 48. Subdivisions of the second section are: $6-12,13-15,16-18,19-23,24-$ 27, 28-31, 32-33, 34-42, and 43-46.

7 Cf. Brueggemann, Walter and W.H. Bellinger, Psalms, New Cambridge Bible commentary (New York: Cambridge University Press, 2014), 458.

8 Richard J. Clifford, Psalms 73-150. Abingdon Old Testament Commentaries (Nashville: Abingdon, 2003), 156.

9 Erhard S. Gerstenberger, Psalms, Part 2, and Lamentations. FOTL 15 (Grand Rapids, MI: Eerdmans, 2001), 244.

10 Allen, Psalms 101-150, 65.

11 Walter Beyerlin, "Der nervus rerum in Psalm 106," Zeitschrift für die alttestamentliche Wissenschaft 86.1 (1974): 50-64. Regarding the psalm's method of renewing Israel's praise, Beyerlin writes, "Sie tut dies, indem sie an Hand der Vätergeschichte gegenwärtige Sündenschuld beichtet und als Lob-Hindernis abbaut. Sie tut es überdies, indem sie der akuten Bedrängnis, die verbittert und stumm gemacht hatte, Anstöße zur Einsicht und Umkehrentnimmt. Und sie versucht es auch damit, daß sie der Geschichtstradition das Zeugnis sich durchhaltender Gotteshuld sowie den Aufschluß abringt, huldvolle Hilfe intendiere letztendlich Jahwes Lobpreisung" (62).

12 Konrad Schaefer, Psalms. Berit Olam (Collegeville, MN: Liturgical Press, 2001), 262. 
but also for the community as a whole. The opening and closing prayers "frame" the narrative of Yahweh's previous saving activity in Israel's history, which functions as the grounds of confidence upon which the prayer for salvation rests. ${ }^{13}$ The narration of Israel's story (vv. 7-46) includes nine episodes of rebellion, beginning with the exodus and extending to the period of the judges. Common to all episodes is the fact that the people turn away from God or revolt against the God-appointed leaders. ${ }^{14}$ However, these narratives illustrate Yahweh's generous forgiveness, which is based in the covenant and, more particularly, in his chronically unfaithful ... nonetheless God has repeatedly forgiven her and shown mercy." 15 Therefore, Joachim Vette can argue that the fate of Israel does not depend upon their merit, but upon God's grace. The series of Israel's rebellious acts is accompanied by a corresponding series of Yahweh's judgments. In response to these punishments, Israel cries out to God, and God relents of the punishments. Repentance happens after, and in response to, the gift of salvation. It is not that repentance leads to redemption, but that redemption leads to repentance. Therefore, praise and repentance are not opposites, but are a twofold appropriate response to the great deeds of God. ${ }^{16}$

\section{The Chiastic Structure of Psalm 106}

Although Psalm 106 is a chronological narrative from verse 7 to verse 46; the structure of the psalm can also be viewed chiastically. Robert Alden observes the following basic A B A' pattern:

A - "Exhortation to praise" (1-5)

B - "Review of exodus rebellions" (6-46)

A' - "Prayer and benediction" (47-48).

Alden also observes the repetition of a number of "key words," such as "salvation," "Hallelujah," "nation," "give thanks," "praise," "forever," and

13 Cf. Hossfeld and Zenger, Psalms 3: A Commentary on Psalms 101-150, 88, 93. The prayer (occurring as it does within a hymn) is 'quite exceptional' (Samuel L. Terrien, The Psalms: Strophic Structure and Theological Commentary, Eerdmans critical commentary [Grand Rapids, MI: Eerdmans, 2003], 731.

${ }_{14}$ Manfred Oeming and JoachimVette. Das Buch Der Psalmen. Nuer Stuttgarter Kommentar Altes Testament. 3 vols. (Stuttgart: Verlag Katholisches Bibelwerk, 2016), III, 104.

15 Schaefer, Psalms, 264.

16 Oeming and Vette. Das Buch Der Psalmen; Vette writes, "Gottes Heilsgeschichte mit Israel ist die Konsequenz seiner Bundesbeziehung mit seinem Volk. Es ist nicht das Verdienst des Volkes, dass sich sein Schicksal wendet; es ist allein Gottes Besinnung auf seine Gnade, die die Strafe enden lässt. Israels Buße geschieht nach dieser Erlösungstat als Reaktion auf die geschenkte Errettung. Nicht Buße führt zur Erlösung, sondern Erlösung führt zur Buße" (III, 105). 
"people;" but he does not arrange the repetitions into a chiastic pattern. ${ }^{17}$ Similarly, Jan P. Fokkelman notes that the "opening and closing stanzas form a clear inclusion" and that v. 48 "is a doxology of which almost every element is linked to the start." 18

Using verbal parallels found in the psalm, I propose the following chiastic structure:

A - Praise the Lord הללויה (1)

B - Forever לעוֹ (1)

C - Praise (2)

D - Prayer for salvation ישע (4)

E - They did not remember (זכר) God's רב חסר) (7)

F - Rebellion by Red Sea מרז (7)

$\mathrm{G}-$ Enemies $(8-12)$

H - They forgot God's works מעשה (13-15)

I - They were jealous of Moses משה (16-18)

J - Moses stood up עמד (19-23)

K - Despised the pleasant land (24)

L - They grumbled in their tents באהליהם

במדבר L' - Yahweh felled them in the wilderness (26)

$\mathrm{K}^{\prime}$ - Scattered to foreign lands ארץ (27)

$\mathbf{J}^{\prime}-$ Phinehas stood up עמד (28-31)

I' - They provoked Moses (32-33)

H' - They learned the Canaanites' works (34-40)

$\mathrm{G}^{\prime}$ - Enemies (41-42)

$\mathrm{F}^{\prime}$ - Rebellion in the time of the judges מרה (43)

E' - God remembered (זכר) covenant and רב (40) (40) (45)

$\mathrm{D}^{\prime}$ - Prayer for salvation ישר (47)

$C^{\prime}$ - Praise תהלה (47)

$\mathrm{B}^{\prime}$ - Forever העוֹ (48)

A' - Praise the Lord הללוייה (48)

My proposal for a chiastic structure is supported by the outlines of both Pierre Auffret and Joachim Vette. Auffret proposes the following chiasm:

17 Robert L. Alden, "Chiastic Psalms (III): A Study in the Mechanics of Semitic Poetry in Psalms 101-150," Journal of the Evangelical Theological Society 21.3 (1978), pp. 201-02.

18 Jan P. Fokkelman, Major Poems of the Hebrew Bible: At the Interface of Hermeneutics and Structural Analysis. Studia Semitica Neerlandica 37 (Assen, The Netherlands: Van Gorcum, 1998), 270. 


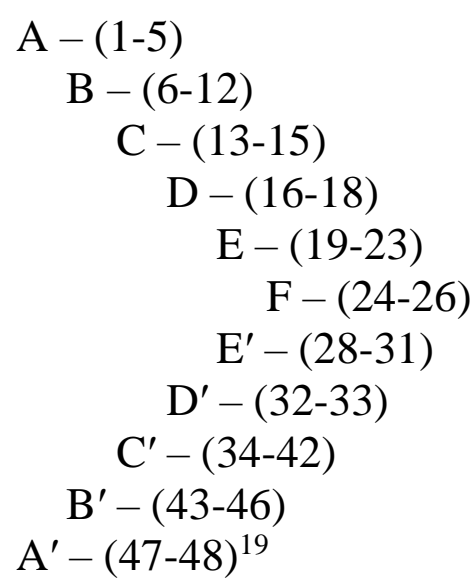

Vette's understanding of the structure is very close to that of Auffret. Vette proposes the following outline:

1-5: Aufforderung zu Lob und Dank

6-12: Rettung am Schilfmeer

13-15: Ungehorsam in der Wüste

16-18: Rebellion im Wüstenlager

19-22: Gotzendienst am Horeb

23: Fürbitte durch Mose

24-27: Zurückweisung des verheißenen Landes

28-29: Frevel von Baal-Peor

30-31: Fürbitte durch Pinhas

32-33: Provokation in Meriba

34-39: Ungehorsam und Frevel bei der Landnahme

40-42: Strafaktion Gottes

43-46: Wendung der Strafe und Bestätigung des Bundes

47: Schlussdoxologie des Psalms

48: Schlussdoxologie des vierten Psalmbuchs ${ }^{20}$

Although Vette does not present his outline in the form of a chiasm, it clearly bears the marks of a chiasm, as may be seen in this slightly modified version that closely resembles Auffret's outline and my own proposed chiastic structure:

19 Pierre Auffret, "'Afin que nous rendions grâce à ton nom': Étude structurelle du Psaume 106," Studi Epigrafici e Linguitici 11 (1994): 75-96.

$20 \quad$ Oeming and Vette. Das Buch Der Psalmen, III, 104. 


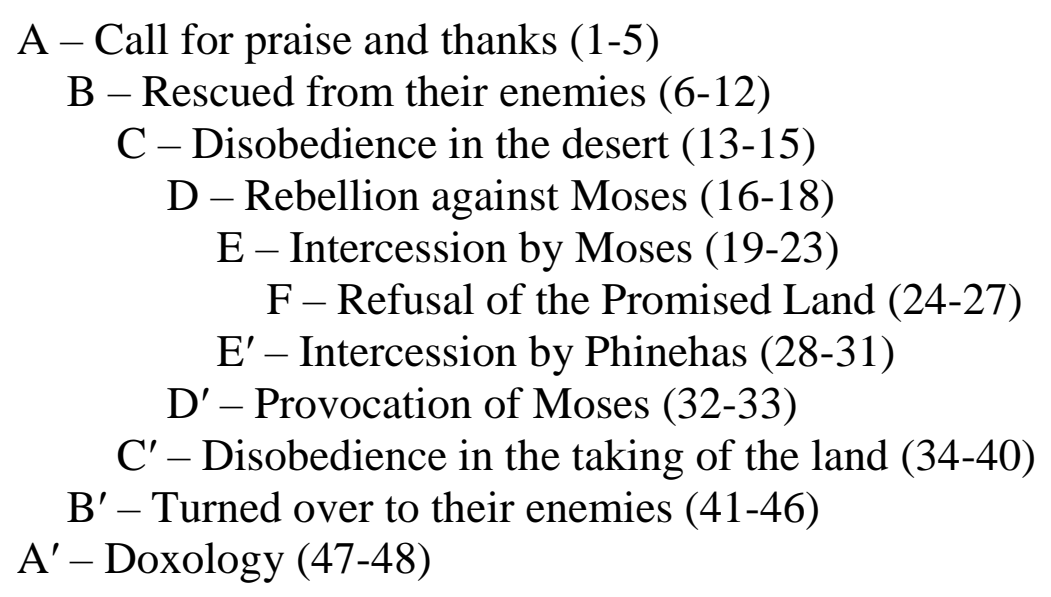

Although similar to both Auffret's and Vette's outlines, my proposal is more detailed and relies on the parallels of specific Hebrew vocabulary. The verbal parallels in the chiastic structure of Psalm 106 highlight a number of key elements that can easily get lost in the lengthy story of Israel's failures. For example, the prayers for salvation (D and $\mathrm{D}^{\prime}$ in my proposed structure) are based upon Yahweh's חס (E and E'), which might be translated as "mercy," "loyalty," or "covenant commitment." 21 The theological paradigm is the exodus, which emphasizes Yahweh's attentive response to Israel's cries. Although the exodus itself is not mentioned at the end of Psalm 106, the language of vv. 44-45 recalls the exodus motif: Yahweh "saw"; Yahweh "heard"; and Yahweh "remembered his covenant" (Exod. 2:24-25). Richard Nysse writes, "The psalmist places the reader at the pivot of Exod 2:23-25. Only now, this is not just past narration. There is a direct move to the present, coming in the form of a petition: 'Save us, O LORD our God, and gather us from among the nations' (106:47). In a sense, Ps 106 calls for a new exodus," in which Israel is brought out of the exile and is returned to the land of Judah. ${ }^{22}$

Within the section that details Israel's unfaithfulness during the time of the judges (vv. 34-40), Auffret has uncovered still another layer of chiastic structure: ${ }^{23}$

21 John Goldingay, Psalms. Baker Commentary on the Old Testament Wisdom and Psalms (3 vols.; Grand Rapids, MI: Baker Academic, 2006), III, 219, translates simply as "commitment." For a helpful discussion of חо, see Hans-Joachim Kraus, Theology of the Psalms. Translated by K.R. Crim. Continental Commentaries (Minneapolis, MN: Augsburg Pub. House, 1986), 44.

22 Richard William Nysse, "Retelling the Exodus," Word \& World 33.2 (2013): 165.

${ }^{23}$ Auffret, "Étude structurelle du Psaume 106," 75-96. 


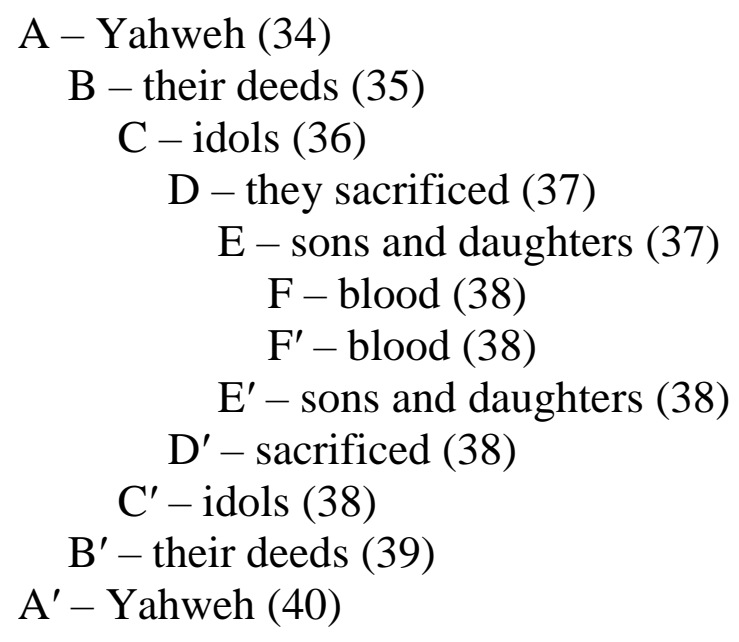

As Allen points out, the chiasm in vv. 34-40 "accentuates the Canaanization of Israel" as a decisive element in Yahweh's choice to punish Israel with exile. ${ }^{24}$

The sins of Israel are characterized as "rebellion" (מרה) (F and F'), which "implies a conscious and wilful attitude, [and] calls attention to the active, subjective participation of the person in his/her position." 25 Even though Israel is rebellious throughout the narrative, both Moses and Phinehas perform heroic actions by "standing up" against the evil ( $\mathrm{J}$ and $\left.\mathrm{J}^{\prime}\right) .{ }^{26}$ The metaphor of "standing up" (עמד) pictures Moses and Phinehas entering the breach "like a brave soldier defending a town from an enemy who wishes to penetrate through an opening in the wall." ${ }^{27}$ Psalm 106, therefore, "gives the office of the intercessor a significant place in God's relation to his sinful people. God answers when he hears the cry that that they lift up on behalf of sinners (v. 44). The psalm itself in its closing petition is such a cry of an intercessor on behalf of his congregation and people." 28 Kugler suggests that the psalm may be calling for intercessors who

$24 \quad$ Allen, Psalms 101-150, 68.

25 Ernst Jenni and Claus Westermann, Theological Lexicon of the Old Testament (Peabody, MA: Hendrickson Publishers, 1997), 687. Dahood unwisely repoints the verb, changing its root from מרר to מרה and translates it as 'hardened'. Mitchell J. Dahood, Psalms, Anchor Bible (3 vols.; Garden City, NY: Doubleday, 1966), III, 75.

26 Jacobson observes that the psalm 'introduces a new theme here, the theme of the importance of the agency of the ancestral leaders' (Nancy L. DeClaissé-Walford, Rolf A. Jacobson, and Beth LaNeel Tanner, The book of Psalms, The New International commentary on the Old Testament (Grand Rapids, MI: Eerdmans, 2014), 803.

27 Gili Kugler, "The Dual Role of Historiography in Psalm 106: Justifying the Present Distress and Demonstrating the Individual's Potential Contribution," Zeitschrift für die alttestamentliche Wissenschaft 126.4 (2014): 550.

28 James Luther Mays, Psalms. Interpretation (Louisville, KY: John Knox Press, 1994), 343. 
will, like Moses and Phinehas, stand up to exilic challenges and bring salvation to Israel. ${ }^{29}$

The role of Moses is emphasized in the chiasm, inasmuch as two episodes of the story center on either jealousy towards Moses or the provocation of Moses (I and I'). Inasmuch as Book IV begins with a psalm attributed to Moses (90) and ends with a psalm that highlights Moses, the Mosaic emphasis of Book IV stands out. Therefore, Erich Zenger has argued that Psalms 90-106 have a Pentateuchal orientation, emphasizing the role of Moses over David within Israel's story. ${ }^{30}$

Yahweh's punishment of Israel in the form of the exile comes into focus by the reference to Israel's rejection of the "pleasant land" and by the reference to Israel's being scattered to foreign lands $\left(\mathrm{K}\right.$ and $\left.\mathrm{K}^{\prime}\right)$. At the center of the chiasm we find further expansion on the reason for the punishment of Israel (both in the wilderness and in the exile) in their refusal to obey God and enter the promised land (Numbers 13-14), a decision that marked the turning point in the book of Numbers (cf. Deut. 1:26-27). Because of Israel's unbelief there, Yahweh swore "to make them fall in the wilderness" and "scatter them" among the nations (vv. 26-27). Gili Kugler reasons, therefore, that the psalmist views the rebellion in the wilderness as the reason for the 40 years of wandering and as a nascent cause for the later Babylonian exile. ${ }^{31}$ It might be argued that the exile (v. 27) is the peak point of Psalm 106 because the exile represents the ultimate punishment of Israel. However, Kugler's argument shows that the emphasis of Psalm 106 is not upon Israel's punishment but upon Israel's rebellion, which necessitates the punishment.

As is shown above, the idolatry of the judges' period contributes to Israel's downfall (vv. 34-44), but the sins that characterized the monarchy, reported

\footnotetext{
29 Kugler, "The Dual Role of Historiography in Psalm 106", 552.

30 Erich Zenger, "The God of Israel's Reign over the World [Psalms 90-106]," Pages 161-90 in The God of Israel and the Nations, ed. N. Lohfink and E. Zenger (Collegeville, MN: Liturgical Press, 2000): 165, 186. A similar argument is presented by Gerald H. Wilson, "Shaping the Psalter: A Consideration of Editorial Linkage in the Book of Psalms," Pages 72-80 in Shape and shaping of the Psalter (Sheffield: JSOT Press, 1993): 75-76. See also Jerome F.D. Creach, 'The Shape of Book Four of the Psalter and the Shape of Second Isaiah', Journal for the Study of the Old Testament 80 (1998): 65; and Krista Mournet, "Moses and the Psalms: The Significance of Psalms 90 and 106 within Book IV of the Masoretic Psalter," Conversations with the Biblical World 31 (2011): 66-79. For a critique of Zenger and Wilson, see Lindsay Wilson, "On Psalms 103-106 as a Closure to Book IV of the Psalter," Pages 755-68 in Composition of the Book of Psalms, ed. E. Zenger, Bibliotheca Ephemeridum Theologicarum Lovaniensium 238 (Leuven: Uitgeverij Peeters, 2010): 755-66.

31 Kugler, "The Dual Role of Historiography in Psalm 106," 547. Kugler argues further that Ezekiel predates Psalm 106 and that the psalmist copied from Ezek. 20:23, which reads, "Nevertheless, I lifted my hand in the desert that I would scatter them among the nations and disperse them throughout the lands" (548).
} 
throughout 1 and 2 Kings, are not mentioned in Psalm 106. In fact, the monarchy is not mentioned at all in the psalm. ${ }^{32}$ The failure to mention the monarchic period makes one wonder if a version of the psalm existed, perhaps, in the Davidic period but was later adapted to speak to the exilic audience.

\section{The Message of Psalm 106}

Based upon Yahweh's covenant faithfulness in the past, Israel is given the courage and faith to plead for forgiveness in their present context, which appears to be the Babylonian exile (v. 47). This version of Israel's story is filled with their repeated violations of their covenant commitment to Yahweh and the subsequent punishments; but despite Israel's continued rebellion, Yahweh's mercy endures, and Israel is saved time and again. Thus, Judith Gärtner writes, "On the basis of his חסד Jhwh turns to his people again and again like at the Red Sea and thereby allows for a continuation of Israel's history." 33 Therefore, Psalm 106 is "a testimony to the fidelity of the Lord in being forgiving, merciful, and faithful to the covenant in spite of Israel's persistent sin." ${ }^{4}$ Yahweh's saving action is initiated when Yahweh remembers "his covenant" (v. 45). Scott Ellington remarks, "The function of this historical recital, then, was to motivate God to forgive in the present based on his long track record as a forgiving God."35

Normally, prayers for repentance take the form that we call lament, but not here. Although Psalm 106 does not take the form of a lament, it functions in much the same way as a lament. Thus, there are different ways to pray for mercy. It is clear that the community is suffering on account of their disobedience. This version of Israel's story creates an entirely different mood from the joyous version that is found in the previous psalm (Ps 105), which recounts the same history from a different perspective. From the more somber tone of Psalm 106, the hearer would be expected to experience feelings of grief and sorrow over Israel's past transgressions. Also, the hearer might be moved toward personal humility toward God and might experience deep gratitude for God's gifts of grace and mercy.

Psalm 106 is a valuable resource for both the individual and the community of faith, and should be read whenever there is a need for God's mercy

\footnotetext{
32 Goldingay, however, views the repeated cycles of rebellion (v. 43) as having reference to "Judges, Kings and Chronicles" (Psalms, III, 237).

33 Judith Gärtner, "The Torah in Psalm 106: Interpretations of JHWH's Saving Act at the Red Sea," Pages 479-88 in Composition of the Book of Psalms. Edited by E. Zenger. Bibliotheca Ephemeridum Theologicarum Lovaniensium 238 (Leuven: Uitgeverij Peeters, 2010), 485.

34 DeClaissé-Walford, Jacobson, and Tanner, The Book of Psalms, 796.

35 Scott A. Ellington, "The Reciprocal Reshaping of History and Experience in the Psalms: Interactions with Pentecostal Testimony." Journal of Pentecostal Theology 16.1 (2007): 25.
} 
and salvation. Leslie Allen writes, "There is a Lenten feel about this psalm for Christian readers, who look back to the cross as a signpost both to the dark reality of human sin and to the saving love of the Father and Son." ${ }^{36}$ John Goldingay suggests that "the declining church in the United States" should "consider the implications of these earlier stories, which illustrate the pattern Ps 106 finds in Israel's story." ${ }^{37}$ This psalm moves the heart toward confession and repentance; and those who hear Psalm 106 are confident that God will forgive, inasmuch as it portrays God as one who in the past has been longsuffering, kind, and merciful to a rebellious people. ${ }^{38}$

\section{THE THEOLOGICAL VALUE OF STORY}

I have written elsewhere about the value of "testimony" to the community of faith. ${ }^{39}$ I pointed out that to some degree, the entire Psalter functions as Israel's testimony to the character and acts of God. ${ }^{40}$ Two types of psalms, however, are more explicitly testimonial in nature: 1 . the thanksgiving psalms and 2. the psalms of historical recital. The thanksgiving psalms recount specific occasions when God intervened in the life of the psalmist to bring help to either the individual or to the community. ${ }^{41}$ Normally, this divine intervention was in response to the psalmist's cry for help as found in the psalms of lament. The psalms of historical recital, however, give more attention to Israel's corporate story and testify to God's saving activity in the history of Israel. In its beginning and ending, this type of psalm bears close similarities to what we call the hymns and may even be classified as a hymn or as an expansion of the hymn type. ${ }^{42}$ Psalm 106, however, is more like a communal lament in its central content.

\footnotetext{
$36 \quad$ Allen, Psalms 101-150, 74.

37 Goldingay, Psalms, III, 240.

38 Cf. Hossfeld and Zenger, Psalms 101-150, 95, where Hossfeld writes, 'The psalm carries confidence of rescue from the end of the psalm to its beginning'.

39 Author (2018): forthcoming.

40 In his Old Testament theology, Walter Brueggemann presents the entire OT as a collection of testimonies regarding Yahweh. The testimonies are generated by what are commonly called the various 'traditions'. See Walter Brueggemann, Theology of the Old Testament: Testimony, Dispute, Advocacy (Minneapolis: Fortress Press, 1997).

${ }^{41}$ Scott A. Ellington, 'The Costly Loss of Testimony', Journal of Pentecostal Theology 16 (2000): 48-59, explores the kinds of testimony offered in the psalms of thanksgiving. Ellington argues that thanksgiving (i.e. testimony) and lament are 'two sides of the same coin' (50-51). See also Ellington, 'The Reciprocal Reshaping of History and Experience in the Psalms', 28-31, in which Ellington elaborates on the nature of Scripture as testimony.

42 An important implication of the call to worship in Psalm 106 is that this testimony (like others in the Psalter) is performed in the context of worship. See Scott A. Ellington, "Can I Get a Witness": The Myth of Pentecostal Orality and the Process of Traditioning in the Psalms', Journal of Pentecostal Theology 20.1 (2011): 9-14.
} 
Like the prose narratives of the Old Testament, the psalms of historical recital are articulations of Israel's theology, ${ }^{43}$ but the psalms are narrative theology set forth in the literary form of lyric poetry. The psalms, therefore, are sung theology. Gerstenberger expresses his amazement at the theological depth and breadth of the Psalms when he writes, "[T]he Psalter does not contain a summa of theological thought or any kind of theological system ... Still, the Psalter is so vast in its theological dimensions that any systematizing effort must fall short. It will continue to stimulate our life of faith even in this different age, just as it has done for centuries." ${ }^{44}$ The psalms of historical recital teach us that theological truth can be learned, taught, handed down, and understood in light of experience. Robert Cate argues that revelation is transmitted through the singing of Psalm 106 because "The mighty acts of God reveal the God of the mighty acts." ${ }^{45}$ Knowledge of God is more than propositional truth; it is relational truth. Scott Ellington adds, "Testimony in the Psalms is an act of traditioning in which Israel's story is brought into the present, experienced anew, and projected into the future." ${ }^{46}$ The God of Psalm 106 is a God who is deeply invested in the life of his people and who responds to their prayers, their confessions, their cries, their praises, and their worship. God intervenes with forgiveness and healing.

\section{CONCLUSION: READING PSALM 106 IN CONTEXT WITH PSALM 105}

Psalms 105 and 106 tell the same story from very different perspectives. Psalm 105 includes no consideration of a rebellious Israel; but Psalm 106 considers little else. Jacobson writes that "whereas Psalm 105 accentuates the positive ... Psalm 106 eliminates the positive." ${ }^{47}$ Terrien argues that Psalms 105 and 106 "contradict and yet complete each other in the dialectic of sin and grace." ${ }^{48}$ I would state it differently and suggest that each of these two psalms is one-sided, telling the story from a single vantage point. Psalm 105 is the story of powerful

43 Goldingay, Psalms, III, 217, states that Psalm 105 'does on a small scale what the great OT narrative works do on a large scale'. Cf. James Limburg, Psalms. Westminster Bible Companion (Louisville, KY: Westminister John Knox Press, 2000), 365-66.

44 Erhard Gerstenberger, Psalms: Part 1, with an Introduction to Cultic Poetry. FOTL 14 (Grand Rapids, MI: Eerdmans, 1988), 36. Cf. Brevard S. Childs, Introduction to the Old Testament as Scripture (Philadelphia: Fortress Press, 1979), who writes that the Psalms 'accurately reflect the theology of Israel' (p. 514). Cf. Goldingay, Psalms, III, 203, who states regarding Psalm 105, 'It is thus teaching; but it is also worship'.

45 Robert L. Cate, 'Psalm 105: The Mighty Acts of God', The Theological Educator 29 (1984): 50.

46 Ellington, 'The Reciprocal Reshaping of History and Experience in the Psalms', 28.

47 DeClaissé-Walford, Jacobson, and Tanner, The Book of Psalms, 796 (emphasis original).

48 Terrien, The Psalms, 733. 
miracles and great victories, but Psalm 106 is the story of miserable failures and deep disappointments.

What do we learn from seeing these two stories side-by-side? First, Psalms 105 and 106 offer two kinds of testimony for two different contexts. Psalm 105 is a celebration of Yahweh's mighty works, and Psalm 106 is a prayer for Yahweh's mercy. We need to hear the optimistic testimony of Psalm 105, especially when we are facing challenges and difficulties. ${ }^{49}$ Nevertheless, when we are living well, it is dangerous only to focus on the positive to the exclusion of our own failings. Therefore, both Psalm 105 and Psalm 106 are needed by the people of God. There are dangers in singing Psalm 105 alone: 1. It can produce unrealistic and unbelievable expectations. 2. It does not prepare for God's discipline. 3. It can lead to a false sense of security. 4. It invites self-confident boasting. 5. It can produce triumphalism and spiritual elitism ("We are the chosen"). 6. It can create an environment that invites disastrous failure and subsequent denial. ${ }^{50}$

These dangers can be avoided by occasionally singing Psalm 106, a psalm that mocks triumphalism, crushes human self-confidence, and shatters the notion that sinning has no consequences. ${ }^{51}$ However, if we sing only Psalm 106, we open ourselves to a different but still unhealthy version of the faith. By itself and in the wrong context, Psalm 106 might lead us to believe that obedience is impossible, continual failure is inevitable, and living under the cloud of God's judgment is our unavoidable destiny - a fatalistic and depressing prospect indeed.

Second, despite their differences, Psalms 105 and 106 share an underlying theology. To put it in the words of Hossfeld, they "draw on the same strand." 52 In addition to the common narrative content regarding the patriarchs, the exodus, and the conquest of Canaan, they contain a number of other verbal parallels. Both psalms refer to Israel as Yahweh's "chosen" $(105.6,43 ; 106.5)$, and both psalms ground Yahweh's saving activity in the "covenant" with Abraham, which Yahweh "remembered" $(105.8,9$, 10, 42; 106.45). Furthermore, in both psalms

49 For example, Goldingay, Psalms, III, 218, suggests that Psalm 105 would be a liberating message 'in the time of Ezra or Nehemiah'.

50 Terrien, The Psalms, 725, asserts that Psalm 105 may represent the 'pious nationalism' and self-assuredness of Jeremiah's enemies. Jacobson adds that 'the history of God's people must never become a glorious narrative of triumph' (DeClaisséWalford, Jacobson, and Tanner, The Book of Psalms, 807).

51 Cf. Terrien, The Psalms, 733, who writes, 'Unlike Psalm 105, this psalm rejects nationalism as a caricature of patriotism that hides collective guilt. The psalmist has been nourished by the realism and honesty of the great prophets, from Amos and Hosea to Isaiah and Micah, and above all from Jeremiah'.

52 Hossfeld and Zenger, Psalms 101-150, 95. 
the acts of Yahweh are described as "wonders" $(105.2,5 ; 106.7,22)$. Based upon these similarities, Walther Zimmerli states:

$\ldots$ in the praise of God the two statements are profoundly joined: the magnifying of the unshakable covenant loyalty of YHWH and the public confession of the sinfulness of the history of the people of God, in which its individual members also know themselves to be involved. This sinfulness leads to a depth out of which only the miracle of God's faithfulness toward his covenant promise can save. The one does not wish to be heard without the other. ${ }^{53}$

\section{BIBLIOGRAPHY}

Auffret, Pierre. "'Afin que nous rendions grâce à ton nom': Étude structurelle du Psaume 106." Studi Epigrafici e Linguitici 11 (1994): 75-96.

Alden, Robert L. "Chiastic Psalms (III): A Study in the Mechanics of Semitic Poetry in Psalms 101-150.” Journal of the Evangelical Theological Society 21.3 (1978): 199-210.

Allen, Leslie C. Psalms 101-150. Word Biblical Commentary, Vol. 21; Waco, TX: Word Books, rev. edn, 2002.

Beyerlin, Walter. "Der nervus rerum in Psalm 106." Zeitschrift für die alttestamentliche Wissenschaft 86.1 (1974): 50-64. https://doi.org/10.1515/zatw.1974.86.1.50

Briggs, Charles Augustus, and Emilie Grace Briggs. A Critical and Exegetical Commentary on the Book of Psalms. International Critical Commentary; 2 vols.; Edinburgh: T. \& T. Clark, 1969.

Brueggemann, Walter. The Psalms and the Life of Faith. Minneapolis, MN: Fortress Press, 1995.

. Theology of the Old Testament: Testimony, Dispute, Advocacy. Minneapolis: Fortress Press, 1997.

Brueggemann, Walter, and W.H. Bellinger. Psalms. New Cambridge Bible Commentary. New York: Cambridge University Press, 2014.

Cate, Robert L. "Psalm 105: The Mighty Acts of God." The Theological Educator 29 (1984): 45-50.

Childs, Brevard S. Introduction to the Old Testament as Scripture. Philadelphia: Fortress Press, 1979.

Clifford, Richard J. Psalms 73-150. Abingdon Old Testament Commentaries. Nashville: Abingdon, 2003.

Creach, Jerome F. D. "The Shape of Book Four of the Psalter and the Shape of Second Isaiah." Journal for the Study of the Old Testament 80 (1998): 63-76. https://doi.org/10.1177/030908929802308004

Dahood, Mitchell J. Psalms. Anchor Bible. 3 vols.; Garden City, NY: Doubleday, 1966. DeClaissé-Walford, Nancy L., Rolf A. Jacobson, and Beth LaNeel Tanner. The Book of Psalms. The New International Commentary on the Old Testament. Grand Rapids, MI: Eerdmans, 2014.

53 Zimmerli, 'Zwillingspsalmen', 261-71. Cited in Hossfeld and Zenger, Psalms 101150,75 . 
Ellington, Scott A. “The Costly Loss of Testimony." Journal of Pentecostal Theology 16 (2000): 48-59. https://doi.org/10.1177/096673690000801603

. "The Reciprocal Reshaping of History and Experience in the Psalms: Interactions with Pentecostal Testimony." Journal of Pentecostal Theology 16.1 (2007): 18-31. https://doi.org/10.1177/0966736907083264

. "Can I Get a Witness': The Myth of Pentecostal Orality and the Process of Traditioning in the Psalms." Journal of Pentecostal Theology 20.1 (2011): 54-67. https://doi.org/10.1163/174552511X554582

Emanuel, David, From Bards to Biblical Exegesis: A Close Reading and Intertextual Analysis of Selected Exodus Psalms. Eugene, OR: Pickwick, 2012.

Fokkelman, Jan P. Major Poems of the Hebrew Bible: At the Interface of Hermeneutics and Structural Analysis. Studia Semitica Neerlandica 37. Assen, The Netherlands: Van Gorcum, 1998.

Gärtner, Judith. "The Torah in Psalm 106: Interpretations of JHWH's Saving Act at the Red Sea." Pages 479-88 in Composition of the Book of Psalms. Edited by E. Zenger. Bibliotheca Ephemeridum Theologicarum Lovaniensium 238. Leuven: Uitgeverij Peeters, 2010.

Gerstenberger, Erhard. Psalms: Part 1, with an Introduction to Cultic Poetry. FOTL 14; Grand Rapids, MI: Eerdmans, 1988.

. Psalms, Part 2, and Lamentations. FOTL 15; Grand Rapids, MI: Eerdmans, 2001.

Goldingay, John. Psalms. Baker Commentary on the Old Testament Wisdom and Psalms. 3 vols.; Grand Rapids, MI: Baker Academic, 2006.

Hossfeld, Frank-Lothar, and Erich Zenger. Psalms 3: A Commentary on Psalms 101150. trans. Linda M. Maloney; Hermeneia; Minneapolis, MN: Fortress Press, 2011.

Jenni, Ernst and Claus Westermann. Theological Lexicon of the Old Testament. Peabody, MA: Hendrickson Publishers, 1997.

Kraus, Hans-Joachim. Theology of the Psalms. Translated by K.R. Crim. Continental Commentaries. Minneapolis, MN: Augsburg Pub. House, 1986.

Kugler, Gili. "The Dual Role of Historiography in Psalm 106: Justifying the Present Distress and Demonstrating the Individual's Potential Contribution." Zeitschrift für die alttestamentliche Wissenschaft 126.4 (2014): 546-53. https://doi.org/10.1515/zaw-2014-0034

Limburg, James. Psalms. Westminster Bible Companion. Louisville, KY: Westminister John Knox Press, 2000.

Mays, James Luther. Psalms. Interpretation. Louisville, KY: John Knox Press, 1994.

Krista Mournet. "Moses and the Psalms: The Significance of Psalms 90 and 106 within Book IV of the Masoretic Psalter." Conversations with the Biblical World 31 (2011): 66-79.

Mowinckel, Sigmund. The Psalms in Israel's worship. 2 Vols in 1. New York: Abingdon Press, 1967.

Nysse, Richard William. "Retelling the Exodus." Word \& World 33.2 (2013): 157-65.

Oeming, Manfred and JoachimVette. Das Buch Der Psalmen. Nuer Stuttgarter Kommentar Altes Testament. 3 vols.; Stuttgart: Verlag Katholisches Bibelwerk, 2016.

Ross, Allen P., A commentary on the Psalms. 3 vols., Kregel Exegetical Library. Grand Rapids, MI: Kregel Academic \& Professional, 2011. 
Martin, “Chiastic Structure of Psalm 106,” OTE 31/3 (2018): 506-521

Schaefer, Konrad. Psalms. Berit Olam. Collegeville, MN: Liturgical Press, 2001.

Terrien, Samuel L. The Psalms: Strophic Structure and Theological Commentary. Eerdmans Critical Commentary. Grand Rapids, MI: Eerdmans, 2003.

Wilson, Gerald H. "Shaping the Psalter: A Consideration of Editorial Linkage in the Book of Psalms." Pages 72-80 in Shape and shaping of the Psalter. Sheffield: JSOT Press, 1993.

Wilson, Lindsay. "On Psalms 103-106 as a Closure to Book IV of the Psalter." Pages 755-68 in Composition of the Book of Psalms, ed. E. Zenger, Bibliotheca Ephemeridum Theologicarum Lovaniensium 238. Leuven: Uitgeverij Peeters, 2010.

Zenger, E. "The God of Israel's Reign over the World (Psalms 90-106)," Pages 161-90 in The God of Israel and the Nations. ed. N. Lohfink and E. Zenger. Collegeville, MN: Liturgical Press, 2000.

Zimmerli, Walther. "Zwillingspsalmen." Pages 261-71 in idem, Studien zur alttestamentlichen Theologie und Prophetie: Gesammelte Aufsätze Band II. Theologische Bücherei 51. Munich: Kaiser, 1974.

Lee Roy Martin, Research Fellow UNISA, Department of Biblical and Ancient Studies and Professor of Old Testament and Biblical Languages at Pentecostal Theological Seminary, USA, Email: lmartin@ptseminary.edu. ORCID ID: https://orcid.org/0000-00002-6582-8373. 